Review

\title{
Pd(II)/HPMoV-Catalyzed Direct Oxidative Coupling Reaction of Benzenes with Olefins
}

\author{
Yasushi Obora * and Yasutaka Ishii * \\ Department of Chemistry and Materials Engineering, Faculty of Chemistry, Materials and \\ Bioengineering and High Technology Research Center, Kansai University, Suita, Osaka 564-8680, \\ Japan
}

* Authors to whom correspondence should be addressed; E-Mails: obora@kansai-u.ac.jp (Y.O.); r091001@kansai-u.ac.jp (Y.I.).

Received: 15 January 2010; in revised form: 2 February 2010 / Accepted: 8 March 2010 / Published: 9 March 2010

\begin{abstract}
The direct aerobic coupling reaction of arenes with olefins was successfully achieved by the use of $\mathrm{Pd}(\mathrm{OAc})_{2}$ /molybdovanadophosphoric acid (HPMoV) as a key catalyst under $1 \mathrm{~atm}$ of dioxygen. This catalytic system could be extended to the coupling reaction of various substituted benzenes with olefins such as acrylates, aclrolein, and ethylene through the direct aromatic C-H bond activation.
\end{abstract}

Keywords: direct coupling; oxidative coupling; arenes; molybdovanadophosphoric acid

\section{Introduction}

The transition-metal-catalyzed arylation of olefins with aryl halides or triflates, which referred to as the Mizoroki-Heck reaction, is an important and a highly versatile C-C bond transformation for the synthesis of arene derivatives [1,2]. However, this existing methodology does not avoid the formation of undesired waste salts arising from the use of aryl halides and bases. Therefore, the development of the direct oxidative couplings of arenes with olefins to afford alkenyl arenes without formation of any salts is highly desired, especially from the environmental and industrial point of view [3-7].

The first waste-free oxidative coupling of arenes was achieved by Fujiwara and Moritani by the stoichiometric reaction of benzene with styrene-palladium chloride dimer in AcOH to give stilbenes in 24\% yield [8]. Thereafter, the same group presented the catalytic aerobic oxidative Mizoroki-Heck 
type reaction by using $\mathrm{Pd}(\mathrm{OAc})_{2}$ combined with $\mathrm{Cu}(\mathrm{OAc})_{2}$ under elevated oxygen pressure (50 atm) [9]. After several modified versions of this prototype reactions were reported [10-12], several practical advances in the development of the catalytic method was evident in recent years [13-15]. For instance, Kitamura and Fujiwara reported that the use of a stoichiometric amount of tert-butyl hydroperoxide as the oxidant in the $\mathrm{Pd}(\mathrm{OAc})_{2}$ combined with benzoquinone as catalysts led to a significant development in more active reoxidation system [13]. Furthermore, Jacobs and coworkers found that the addition of small amounts (4-20 mol \%) of $\mathrm{Mn}(\mathrm{OAc})_{3}$ or benzoic acid are effective for the Pd(II)-catalyzed oxidative Mizoroki-Heck type reaction under $8 \mathrm{~atm}$ of $\mathrm{O}_{2}$ [14]. This methodology has been recently extended to the Pd (II)-catalyzed C-H bond alkenylation of anilides and heteroarenes such as pyrroles and indoles [15-17].

In this review, we summarize recent progress from our laboratory in terms of the aerobic oxidative coupling reaction of arenes with olefins such as acrylates [18,19], $\alpha, \beta$-unsaturated aldehydes [20,21] as well as ethylene [22] under ambient dioxygen atmosphere by using $\operatorname{Pd}(\mathrm{OAc})_{2} /$ molybdovanadophosphoric acid (HPMoV) as a key catalyst system.

\section{Results and Discussion}

\subsection{Oxidative Mizoroki-Heck type coupling reaction of arenes with acrylates}

The reaction of benzene (1a) with ethyl acrylate was chosen as a model reaction and carried out under various reaction conditions (Equation 1). The results are shown in Table 1.

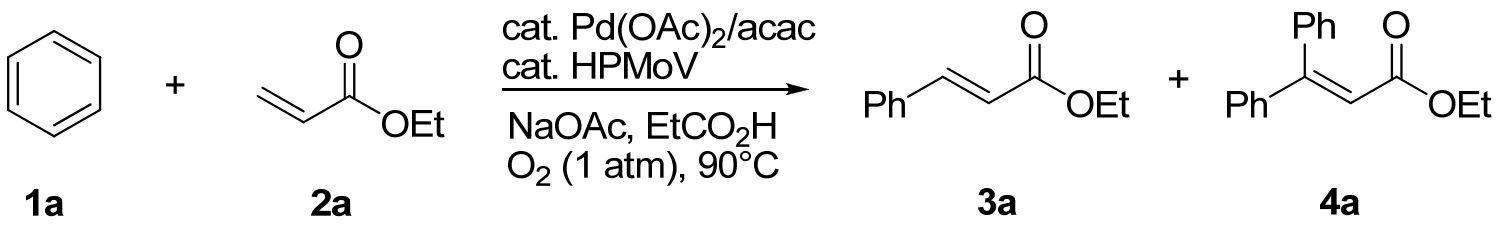

The coupling reaction of $1 \mathbf{a}(30 \mathrm{mmol})$ and $\mathbf{2 a}(1.5 \mathrm{mmol})$ catalyzed by $\mathrm{Pd}(\mathrm{OAc})_{2}(0.1 \mathrm{mmol}$, $6.7 \mathrm{~mol} \%)$ combined with $\mathrm{H}_{4} \mathrm{PMo}_{11} \mathrm{VO}_{40} \cdot 30 \mathrm{H}_{2} \mathrm{O}\left(\mathrm{HPMo}_{11} \mathrm{~V}_{1}, 0.02 \mathrm{mmol}, 1.3 \mathrm{~mol} \%\right)$ proceeded smoothly in the presence of small amounts of acetylacetone $(0.1 \mathrm{mmol}, 6.7 \mathrm{~mol} \%)$ and $\mathrm{NaOAc}$ ( $0.08 \mathrm{mmol}, 5.3 \mathrm{~mol} \%$ ) under $1 \mathrm{~atm}$ of $\mathrm{O}_{2}$ in propionic acid at $90{ }^{\circ} \mathrm{C}$ for $2.5 \mathrm{~h}$ to give ethyl cinnamate (3a) and ethyl $\beta$-phenylcinnamate (4a) in $74 \%$ and $13 \%$ yields, respectively. In this reaction, ethyl 3propionyloxyacrylate (5) derived from 2a and propionic acid was obtained in $4 \%$ as by-products (entry 1). The product distribution of $\mathbf{3 a}$ and $\mathbf{4 a}$ was controlled by the reaction time. When the reaction time was prolonged to 5 h, 4a was formed in good yield (81\%) as a major adduct (entry 2). Removing of NaOAc or acetylacetone from the present catalytic system resulted in the decrease of the coupling products, 3a and 4a (entries 3 to 4). It is considered that acetylacetone would be functioned as a ligand in the catalyst system, and the addition of acetylacetone is not necessary when $\operatorname{Pd}(\operatorname{acac})_{2}$ was employed in place of $\mathrm{Pd}(\mathrm{OAc})_{2}$ (entry 5). The use of excess amount of $\mathbf{1 a}$ is favorable and when the amount of 1a was reduced from $30 \mathrm{mmol}$ to $6 \mathrm{mmol}$, the yield of 3a decreased to $51 \%$ and the yield of 5 was increased from $4 \%$ to $16 \%$ (entry 6). As for a choice of a solvent in this reaction, the use of acetic acid instead of propionic acid resulted in considerable decrease of the yields of $\mathbf{3 a}$ and $\mathbf{4 a}$ (entry 7). The yield of coupling products, $\mathbf{3 a}$ and $\mathbf{4 a}$, was markedly influenced by the combination of 
$\mathrm{Pd}(\mathrm{OAc})_{2}$ with molybdovanadophosphoric acids (HPMoV) which serve as reoxidation catalysts of the reduced $\mathrm{Pd}(0)$ to $\mathrm{Pd}(\mathrm{II})$ during the reaction course. Thus, the reaction was sluggish in the absence of HPMoV (entry 8). The performance of various heteropoly acid including HPMoV as reoxidation catalysts was affected by the vanadium content in the heteropolyacid (entries 9 to 12). The reaction by the use of 12-molybdophosphoric acid $\left(\mathrm{HPMo}_{12}\right)$ not involving $\mathrm{V}$ ion brought about 3a in low yield (52\%) (entry 12). In addition, the effect of several alkali metal acetates as a base, was examined. As a result, $\mathrm{NaOAc}$ was found to be the best base in the present catalytic system (entry 1 vs. entries 13-16). One of the most important feature of this method is that the reaction smoothly proceeded under $1 \mathrm{~atm}$ of $\mathrm{O}_{2}$. Moreover, it is useful from the practical synthetic viewpoint that the reaction tolerated under air in place of pure $\mathrm{O}_{2}$, and 3a was obtained in 74\% yield for $5 \mathrm{~h}$ (entry 17). However, the reaction in the absence of dixoygen, namely under $\operatorname{Ar}(1 \mathrm{~atm})$, was difficult to take place (entry 18).

Table 1. Oxidative coupling of benzene (1a) with ethyl acrylate (2a) catalyzed by $\mathrm{Pd}(\mathrm{II}) / \mathrm{HPMoV}$. $^{\mathrm{a}}$

\begin{tabular}{|c|c|c|c|c|c|}
\hline \multirow{2}{*}{ Entry } & \multirow{2}{*}{ HPMoV } & \multirow{2}{*}{ Base } & \multicolumn{3}{|c|}{ Yield $/ \%{ }^{\text {b }}$} \\
\hline & & & 3a & $4 a$ & 5 \\
\hline 1 & $\mathrm{H}_{4} \mathrm{PMo}_{11} \mathrm{VO}_{40} \cdot 30 \mathrm{H}_{2} \mathrm{O}$ & $\mathrm{NaOAc}$ & 74 & 13 & 4 \\
\hline $2^{c}$ & $\mathrm{H}_{4} \mathrm{PMo}_{11} \mathrm{VO}_{40} \cdot 30 \mathrm{H}_{2} \mathrm{O}$ & $\mathrm{NaOAc}$ & 6 & 81 & $\mathrm{nd}^{\mathrm{d}}$ \\
\hline 3 & $\mathrm{H}_{4} \mathrm{PMo}_{11} \mathrm{VO}_{40} \cdot 30 \mathrm{H}_{2} \mathrm{O}$ & None & 6 & $\mathrm{nd}^{\mathrm{d}}$ & 4 \\
\hline $4^{\mathrm{e}}$ & $\mathrm{H}_{4} \mathrm{PMo}_{11} \mathrm{VO}_{40} \cdot 30 \mathrm{H}_{2} \mathrm{O}$ & $\mathrm{NaOAc}$ & 53 & 2 & 8 \\
\hline $5^{e, f}$ & $\mathrm{H}_{4} \mathrm{PMo}_{11} \mathrm{VO}_{40} \cdot 30 \mathrm{H}_{2} \mathrm{O}$ & $\mathrm{NaOAc}$ & 75 & 16 & 1 \\
\hline $6^{g}$ & $\mathrm{H}_{4} \mathrm{PMo}_{11} \mathrm{VO}_{40} \cdot 30 \mathrm{H}_{2} \mathrm{O}$ & $\mathrm{NaOAc}$ & 51 & 5 & 16 \\
\hline $7^{\mathrm{h}}$ & $\mathrm{H}_{4} \mathrm{PMo}_{11} \mathrm{VO}_{40} \cdot 30 \mathrm{H}_{2} \mathrm{O}$ & $\mathrm{NaOAc}$ & 20 & nd $^{\mathrm{d}}$ & nd $^{\mathrm{d}}$ \\
\hline 8 & None & $\mathrm{NaOAc}$ & 9 & nd $^{\mathrm{d}}$ & 1 \\
\hline 9 & $\mathrm{H}_{5} \mathrm{PMo}_{10} \mathrm{~V}_{2} \mathrm{O}_{40} \cdot 28 \mathrm{H}_{2} \mathrm{O}$ & $\mathrm{NaOAc}$ & 73 & 14 & 5 \\
\hline 10 & $\mathrm{H}_{6} \mathrm{PMo}_{9} \mathrm{~V}_{3} \mathrm{O}_{40} \cdot 30 \mathrm{H}_{2} \mathrm{O}$ & $\mathrm{NaOAc}$ & 70 & 13 & 5 \\
\hline 11 & $\mathrm{H}_{7} \mathrm{PMo}_{8} \mathrm{~V}_{4} \mathrm{O}_{40} \cdot 28 \mathrm{H}_{2} \mathrm{O}$ & $\mathrm{NaOAc}$ & 62 & 4 & 5 \\
\hline 12 & $\mathrm{H}_{3} \mathrm{PMo}_{12} \mathrm{O}_{40} \cdot 30 \mathrm{H}_{2} \mathrm{O}$ & $\mathrm{NaOAc}$ & 43 & 1 & 4 \\
\hline 13 & $\mathrm{H}_{4} \mathrm{PMo}_{11} \mathrm{VO}_{40} \cdot 30 \mathrm{H}_{2} \mathrm{O}$ & $\mathrm{LiOAc}$ & 66 & 5 & 7 \\
\hline 14 & $\mathrm{H}_{4} \mathrm{PMo}_{11} \mathrm{VO}_{40} \cdot 30 \mathrm{H}_{2} \mathrm{O}$ & $\mathrm{CsOAc}$ & 13 & nd $^{\mathrm{d}}$ & 1 \\
\hline 15 & $\mathrm{H}_{4} \mathrm{PMo}_{11} \mathrm{VO}_{40} \cdot 30 \mathrm{H}_{2} \mathrm{O}$ & KOAc & 11 & nd $^{\mathrm{d}}$ & nd $^{\mathrm{d}}$ \\
\hline 16 & $\mathrm{H}_{4} \mathrm{PMo}_{11} \mathrm{VO}_{40} \cdot 30 \mathrm{H}_{2} \mathrm{O}$ & $\mathrm{NH}_{4} \mathrm{OAc}$ & 12 & nd $^{\mathrm{d}}$ & nd $^{\mathrm{d}}$ \\
\hline $17^{\mathrm{i}}$ & $\mathrm{H}_{4} \mathrm{PMo}_{11} \mathrm{VO}_{40} \cdot 30 \mathrm{H}_{2} \mathrm{O}$ & $\mathrm{NaOAc}$ & 74 & 8 & 6 \\
\hline $18^{\mathrm{j}}$ & $\mathrm{H}_{4} \mathrm{PMo}_{11} \mathrm{VO}_{40} \cdot 30 \mathrm{H}_{2} \mathrm{O}$ & $\mathrm{NaOAc}$ & 10 & $\mathrm{Nd}^{\mathrm{d}}$ & 3 \\
\hline
\end{tabular}

${ }^{\mathrm{a}}$ A mixture of $1 \mathbf{a}(30 \mathrm{mmol})$ and $\mathbf{2 a}(1.5 \mathrm{mmol})$ was reacted in the presence of Pd-catalyst (0.1 mmol, $6.7 \mathrm{~mol} \%)$, HPMoV (0.02 mmol, $1.3 \mathrm{~mol} \%)$, base $(0.08 \mathrm{mmol}, 5.3 \mathrm{~mol} \%)$ and acetylacetone (0.1 mmol, $6.7 \mathrm{~mol} \%)$ in EtCOOH ( $5 \mathrm{~mL}$ ) at $90{ }^{\circ} \mathrm{C}$ for $2.5 \mathrm{~h} .{ }^{\mathrm{b}} \mathrm{GC}$ yield based on 2a used. ${ }^{\mathrm{c}}$ Reaction time was $5 \mathrm{~h} .{ }^{\mathrm{d}}$ Not detected by GC. ${ }^{\mathrm{e}}$ The reaction was performed in the absence of acetylacetone. ${ }^{\mathrm{f}} \mathrm{Pd}(\mathrm{acac})_{2}$ was used as catalyst. ${ }^{\mathrm{g}} \mathbf{1 a}(6 \mathrm{mmol})$ was used. ${ }^{\mathrm{h}} \mathrm{AcOH}$ was used instead of EtCOOH. ${ }^{i}$ The reaction was performed under air $(1 \mathrm{~atm})$ for $5 \mathrm{~h} .{ }^{\mathrm{j}}$ The reaction was performed under argon (1 atm).

Various arenes (1) were allowed to react with acrylates $\mathbf{2}$ under the optimized reaction conditions. These results are summarized in Table 2. Benzene (1a) reacted smoothly with several acrylates $\mathbf{2 b}$-2e to give the corresponding cinnamates $\mathbf{3 b - 3 d}$ in $68-73 \%$ yields with concomitant formation of $\beta$-phenylcinnamate in $11-16 \%$ yields (entries 1 to 3 ). The arylation of 4-phenyl-2-butenone (2e) under 
these reaction conditions gave 1,1-diphenyl-3-butenone (3e) in 93\% yield (entry 4). Reaction of various arenes with ethyl acrylate (2a) was also carried out under optimized reaction conditions (entries 4-10). The reaction of toluene (1b) with 2a afforded the coupling products $\mathbf{3 f}$ in $70 \%$ total yield as a isomeric mixture consisting of $o-3 \mathbf{f}: m-3 \mathbf{f}: p$-3f $=15: 41: 44$ (entry 5).

Table 2. Oxidative coupling of various arenes 1 and acrylates 2 catalyzed by $\mathrm{Pd}(\mathrm{II}) / \mathrm{HPMoV}$. $^{\mathrm{a}}$

Entry

${ }^{\text {a }}$ A mixture of arene $1(30 \mathrm{mmol})$ and olefins $2(1.5 \mathrm{mmol})$ was reacted in the presence of Pdcatalyst (0.1 mmol, $6.7 \mathrm{~mol} \%), \mathrm{H}_{4} \mathrm{PMo}_{11} \mathrm{VO}_{40} \cdot 30 \mathrm{H}_{2} \mathrm{O}$ (0.02 mmol, $\left.1.3 \mathrm{~mol} \%\right)$, NaOAc (0.08 mmol, $5.3 \mathrm{~mol} \%)$ and acetylacetone ( $0.1 \mathrm{mmol}, 6.7 \mathrm{~mol} \%)$ in EtCOOH $(5 \mathrm{~mL}) .{ }^{\mathrm{b}} \beta$-methylcinnamates are formed in $11-16 \%$ yields as by-products. ${ }^{\mathrm{c}}$ Ratio of o:m:p. ${ }^{\mathrm{d}}$ Ethyl cinnamate was obtained in $5 \%$. ${ }^{\mathrm{e}}$ Arene $(5 \mathrm{mmol})$ was used. ${ }^{\mathrm{g}}$ Arene $(3 \mathrm{mmol})$ was used. ${ }^{\mathrm{h}} 5 \mathrm{wt} \% \mathrm{Pd}(\mathrm{OAc})_{2} / \mathrm{C}$ was used instead of $\mathrm{Pd}(\mathrm{OAc})_{2}$. 
Anisole (1c) was subjected to react with $\mathbf{2 a}$ at $60{ }^{\circ} \mathrm{C}$ to give a mixture of coupling products $\mathbf{3 g}$ in 73\% total yield (entry 6). The reaction of chlorobenzene (1d) and bromobenzene (1e) with 2a gave the corresponding oxidative coupling products, $3 \mathbf{h}$ and $3 \mathbf{i}$ exclusively, in $74 \%$ and $49 \%$ yields, respectively. It is noteworthy that the reaction of $\mathbf{1 d}$ and $\mathbf{1 e}$ gave oxidative coupling products exclusively, in preference to the products based on the Mizoroki-Heck reaction (entries 7 and 8). The reaction of 1,2-dimethoxybenzene (1f) with $\mathbf{2 a}$ afforded ethyl 3,4-dimethoxycinnamate (3j) in 67\% yield (entry 9). Unfortunately, the reaction of 2-methyl-thiophene (1g) with 2a under the abovementioned reaction conditions did not take place at all. Alternatively, $\mathrm{Pd}(\mathrm{OAc})_{2}$ supported on active carbon, $\mathrm{Pd}(\mathrm{OAc})_{2} / \mathrm{C}$, was efficient for the coupling of $\mathbf{1 g}$ with 2a to give the corresponding coupling product, $3 \mathbf{k}$, in $86 \%$ yield (entry 10 ).

In this reaction, reoxidation step is important to determine the turn-over number (TON) of the present reaction, which was markedly affected by the choice of HPMoV catalysts. Therefore, the reaction of $1 \mathbf{a}(45 \mathrm{mmol})$ and $2 \mathbf{a}(3 \mathrm{mmol})$ was carried out in the presence of $\mathrm{Pd}(\mathrm{OAc})_{2}(0.03 \mathrm{mmol})$, HPMoV (0.02 mmol), NaOAc (0.08 mmol), acetylacetone $(0.03 \mathrm{mmol})$, and EtCOOH $(5 \mathrm{~mL})$ under $\mathrm{O}_{2}(1 \mathrm{~atm})$ at $90{ }^{\circ} \mathrm{C}$ for $12 \mathrm{~h}$. The results of TONs for the formation of 3a and 4a by using various $\mathrm{HPMoV}$ under these conditions were as follows: 19 for $\mathrm{H}_{3} \mathrm{PMo}_{12} \mathrm{O}_{40} \cdot 30 \mathrm{H}_{2} \mathrm{O}, 76$ for $\mathrm{H}_{4} \mathrm{PMo}_{11} \mathrm{VO}_{40} \cdot 30 \mathrm{H}_{2} \mathrm{O}$, 10 for $\mathrm{H}_{5} \mathrm{PMo}_{10} \mathrm{~V}_{2} \mathrm{O}_{40} \cdot 28 \mathrm{H}_{2} \mathrm{O}$, 8 for $\mathrm{H}_{6} \mathrm{PMo}_{9} \mathrm{~V}_{3} \mathrm{O}_{40} \cdot 30 \mathrm{H}_{2} \mathrm{O}$, and 6 for $\mathrm{H}_{7} \mathrm{PMo}_{8} \mathrm{~V}_{4} \mathrm{O}_{40} \cdot 28 \mathrm{H}_{2} \mathrm{O}$.

We previously reported that combined catalysts of $\mathrm{Pd}(\mathrm{OAc})_{2}$ with $\mathrm{HPMo}_{11} \mathrm{~V}_{1}$ and $\mathrm{HPMo}_{12}$ as the reoxidation catalyst was the most active for the Pd-catalyzed oxidative coupling of benzene to biphenyl under $\mathrm{O}_{2}(1 \mathrm{~atm})$ [23]. In the present reaction, the best TON (121) was observed by the reaction in the presence of $\mathrm{Pd}(\mathrm{OAc})_{2}$ combined with a $1: 1$ mixture of $\mathrm{HPMo}_{11} \mathrm{~V}_{1}$ and $\mathrm{HPMo}_{12}$ under these reaction conditions.

To obtain mechanistic information on the present reaction, the initial rate of the reaction of benzene 1a with 2a was compared with that of benzene- $d_{6}\left(\mathbf{1}_{-}-\mathbf{d}\right)$ with $\mathbf{2 a}$ under the same conditions as entry 1 in Table 1. It was found that a kinetic isotope effect for the coupling reaction was evident and the rate of the reaction of $\mathbf{1 a}$ with $\mathbf{2 a}$ was four times faster than that of benzene- $d_{6}\left(\mathbf{1} \mathbf{a}_{-\boldsymbol{d}}\right)$ with $\mathbf{2 a}$, i.e., $k_{\mathrm{H}} / k_{\mathrm{D}} \approx 4$. The same results $\left(k_{\mathrm{H}} / k_{\mathrm{D}} \approx 4\right)$ were obtained by the reaction of a 1:1 mixture of $1 \mathbf{a}$ and $1 \mathbf{a}_{-\boldsymbol{d}}$ with 2a under these conditions. These facts indicate that the cleavage of the $\mathrm{C}-\mathrm{H}$ bond of the $\mathbf{1 a}$ is the rate-determining step in a sequence of reactions.

Although a detailed reaction mechanism remains to be further elucidated, it is possible to explain the reaction rationally by a pathway similar to that proposed by Kitamura and Fujiwara [13]. A plausible reaction path is shown in Scheme 1. First, electrophilic attack of a Pd(II) to arene $\mathbf{1}$ would initiate the reaction, leading to a $\sigma$-aryl-palladium (II) intermediate (A), which is considered to be the rate-determining step by judging from the labeled experiment (vide supra). The insertion of olefins like acrylate 2 to $\sigma$-aryl-palladium (II) intermediate (A) takes place to give $\sigma$-alkyl-palladium (II) intermediate $\mathbf{B}$. Subsequently, $\beta$-hydride elimination of the $\mathbf{B}$ gives the desired coupling products $\mathbf{3}$ along with $\mathrm{Pd}-\mathrm{H}$ intermediate. The $\mathrm{Pd}-\mathrm{H}$ intermediate is reduced to $\operatorname{Pd}(0)$, and the resulting $\operatorname{Pd}(0)$ species is reoxidized by [HPMoV]ox. to generate initial $\mathrm{Pd}(\mathrm{II})$ catalyst. The [HPMoV]red. is easily oxidized to [HPMoV]ox. with atomospheric dioxygen. 
Scheme 1. A possible reaction path for the coupling of arene with acrylate.

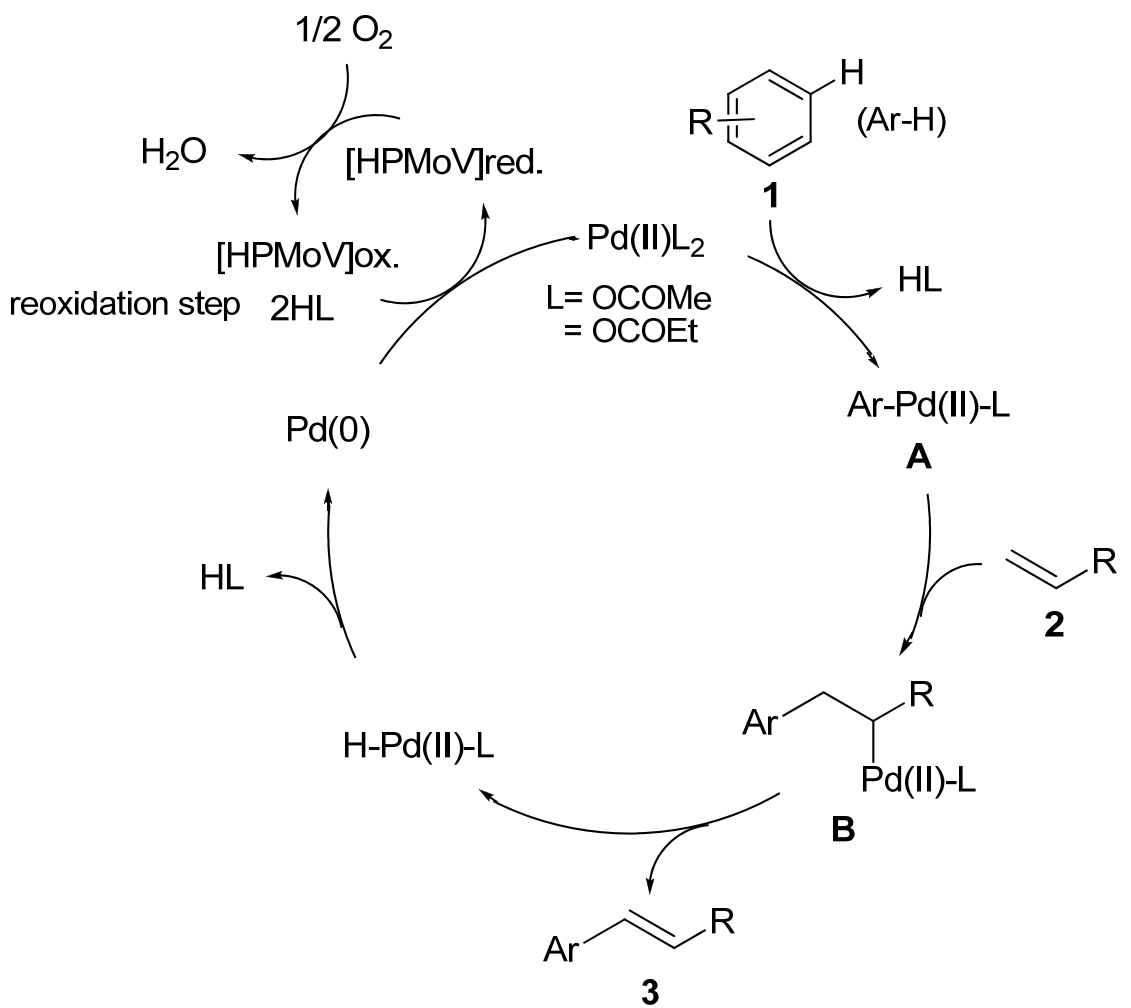

\subsection{Oxidative Mizoroki-Heck type coupling of benzenes with $\alpha, \beta$-unsaturated aldehydes}

The oxidative coupling reaction of benzene (1a) with $\alpha, \beta$-unsaturated aldehydes such as acrolein (6a) was also achieved by slight modifications of the reaction conditions as reported in section 2.1., which leads to cinnamaldehyde (7a) and $\beta$-phenyl cinnamaldehyde (8) as products (Equation 2).

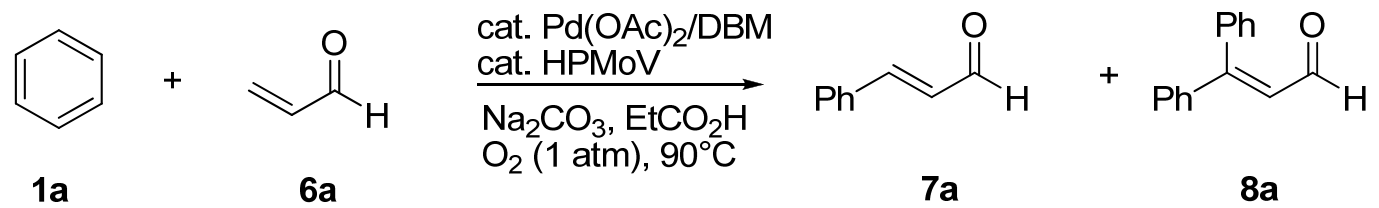

The results of the reaction of 1a with $\mathbf{6 a}$ under various conditions are summarized in Table 3. The best result for the formation of cinnamaldehyde (7a) was attained by the reaction conditions as shown in Table 3, entry 1. Namely, a mixture of $\mathbf{1}(30 \mathrm{mmol})$ and $\mathbf{6 a}(1.5 \mathrm{mmol})$ was allowed to react under the influence of $\mathrm{Pd}(\mathrm{OAc})_{2}(0.1 \mathrm{mmol}, 6.7 \mathrm{~mol} \%), \mathrm{H}_{4} \mathrm{PMo}_{11} \mathrm{VO}_{40} \cdot 26 \mathrm{H}_{2} \mathrm{O}\left(\mathrm{HPMo}_{11} \mathrm{~V}_{1}\right.$, $0.02 \mathrm{mmol}, 1.3 \mathrm{~mol} \%), \mathrm{Na}_{2} \mathrm{CO}_{3}$ (0.05 mmol, $3.4 \mathrm{~mol} \%$ ), and dibenzoylmethane (DBM) (0.1 mmol, $6.7 \mathrm{~mol} \%)$ under $\mathrm{O}_{2}(1 \mathrm{~atm})$ in propionic acid $(5 \mathrm{~mL})$ at $90{ }^{\circ} \mathrm{C}$ for $1.5 \mathrm{~h}$, giving $7 \mathrm{a}$ in $59 \%$ yield along with 8 (5\%). In the present reaction, a trace amount of cinnamic acid was detected by GC. Similar to the reaction of 1a and acrylate $\mathbf{2 a}$ (see Section 2.1), prolonged reaction time resulted in dicoupling product 8a as a major product rather than $\mathbf{3}$ (entries $1-4$ ). The maximum yield of 7a was attained in $1.5 \mathrm{~h}$ (entries 1). The best yield of $7 \mathbf{a}$ was obtained when the reaction was carried out by using the excess amount of $\mathbf{1 a}(30 \mathrm{mmol})$ to $\mathbf{6 a}(1.5 \mathrm{mmol})$. However, the yield of $\mathbf{7 a}$ was still good to high 
when the amount of $\mathbf{1}$ was reduced to $20 \mathrm{mmol}$ (entry 5). The addition of DBM as a ligand was effective in the present reaction and the yield of $\mathbf{7 a}$ in the absence of a DBM ligand resulted in a decrease of the yield of 7a to 33\% (entry 6). As for a ligand, the use of benzoylacetone led to a similar result as that of DBM (entry 7). When acetylacetone (acacH) which is an effective ligand in the reaction of 1a and 2a (section 2.1) was employed instead of DBM, longer reaction time is needed to obtain the same catalytic activity (entries 8 and 9). The addition of the base is indispensible in the reaction and the reaction in the absence of $\mathrm{Na}_{2} \mathrm{CO}_{3}$ resulted in a considerable decrease of the yield of 7a and 8a, and several unidentified products (probably oligomers of 6a) were formed (entry 10). A slight decrease of the yield of 7a was observed when NaOAc was added as a base (entry 11).

Furthermore, the effect of the HPMoV was examined under the reaction conditions as entry 1 , Table 3 (entries 12-16). The best result was obtained by using $\mathrm{H}_{4} \mathrm{PMo}_{10} \mathrm{VO}_{40} \cdot 26 \mathrm{H}_{2} \mathrm{O}$ to afford $7 \mathbf{a}$ in $59 \%$ yield as shown in entry 1 . Increase of the $\mathrm{V}$ content in the HPMoV was found to bring about a decrease of the yields of 7a (entries 12-14). Moreover, vanadotungstphosphoric acid $\left(\mathrm{H}_{5} \mathrm{PW}_{10} \mathrm{~V}_{2} \mathrm{O}_{40} \cdot 27 \mathrm{H}_{2} \mathrm{O}\right)$ did not catalyze the present coupling reaction at all (entry 15). $\mathrm{H}_{3} \mathrm{PMo}_{12} \mathrm{O}_{40} \cdot 30 \mathrm{H}_{2} \mathrm{O}$ not containing a vanadium atom was less efficient catalyst than $\mathrm{HPMoV}$ (entry 16).

In this reaction, acrolein (6a) was rapidly consumed when the reaction started, and the coupling product 7a was reached maximum after $1.5 \mathrm{~h}$, and gradually decreased because of further coupling with 1a leading to dicoupling product 8a. To confirm this sequential pathway for the formation of $\mathbf{8 a}$, an independent reaction of $\mathbf{7 a}$ with $\mathbf{1}$ under these conditions gave $\mathbf{8 a}$ in $61 \%$ yield.

Table 3. Oxidative coupling of benzene (1a) with acrolein (6a) catalyzed by Pd(II)/HPMoV. ${ }^{a}$

\begin{tabular}{|c|c|c|c|c|c|}
\hline \multirow{2}{*}{ Entry } & \multirow{2}{*}{ HPMoV } & \multirow{2}{*}{ Ligand } & \multirow{2}{*}{ Time/h } & \multicolumn{2}{|c|}{ Yield $/ \%^{b}$} \\
\hline & & & & $7 a$ & $8 a$ \\
\hline 1 & $\mathrm{H}_{4} \mathrm{PMo}_{11} \mathrm{VO}_{40} \cdot 26 \mathrm{H}_{2} \mathrm{O}$ & DBM & 1.5 & 59 & 5 \\
\hline 2 & $\mathrm{H}_{4} \mathrm{PMo}_{11} \mathrm{VO}_{40} \cdot 26 \mathrm{H}_{2} \mathrm{O}$ & DBM & 1 & 26 & nd $^{\mathrm{d}}$ \\
\hline 3 & $\mathrm{H}_{4} \mathrm{PMo}_{11} \mathrm{VO}_{40} \cdot 26 \mathrm{H}_{2} \mathrm{O}$ & DBM & 2 & 45 & 18 \\
\hline 4 & $\mathrm{H}_{4} \mathrm{PMo}_{11} \mathrm{VO}_{40} \cdot 26 \mathrm{H}_{2} \mathrm{O}$ & DBM & 3 & 17 & 40 \\
\hline $5^{c}$ & $\mathrm{H}_{4} \mathrm{PMo}_{11} \mathrm{VO}_{40} \cdot 26 \mathrm{H}_{2} \mathrm{O}$ & DBM & 1.5 & 53 & 6 \\
\hline 6 & $\mathrm{H}_{4} \mathrm{PMo}_{11} \mathrm{VO}_{40} \cdot 26 \mathrm{H}_{2} \mathrm{O}$ & None & 1.5 & 33 & nd $^{\mathrm{d}}$ \\
\hline 7 & $\mathrm{H}_{4} \mathrm{PMo}_{11} \mathrm{VO}_{40} \cdot 26 \mathrm{H}_{2} \mathrm{O}$ & benzoylacetone & 1.5 & 52 & 6 \\
\hline 8 & $\mathrm{H}_{4} \mathrm{PMo}_{11} \mathrm{VO}_{40} \cdot 26 \mathrm{H}_{2} \mathrm{O}$ & acacH & 1.5 & 48 & 1 \\
\hline 9 & $\mathrm{H}_{4} \mathrm{PMo}_{11} \mathrm{VO}_{40} \cdot 26 \mathrm{H}_{2} \mathrm{O}$ & асасH & 2 & 54 & 8 \\
\hline $10^{\mathrm{e}}$ & $\mathrm{H}_{4} \mathrm{PMo}_{11} \mathrm{VO}_{40} \cdot 26 \mathrm{H}_{2} \mathrm{O}$ & acacH & 2 & 3 & nd $^{\mathrm{d}}$ \\
\hline $11^{\mathrm{f}}$ & $\mathrm{H}_{4} \mathrm{PMo}_{11} \mathrm{VO}_{40} \cdot 26 \mathrm{H}_{2} \mathrm{O}$ & асасH & 2 & 44 & 2 \\
\hline 12 & $\mathrm{H}_{5} \mathrm{PMo}_{10} \mathrm{~V}_{2} \mathrm{O}_{40} \cdot 28 \mathrm{H}_{2} \mathrm{O}$ & DBM & 1.5 & 54 & 6 \\
\hline 13 & $\mathrm{H}_{6} \mathrm{PMo}_{10} \mathrm{~V}_{3} \mathrm{O}_{40} \cdot 30 \mathrm{H}_{2} \mathrm{O}$ & DBM & 1.5 & 47 & 6 \\
\hline 14 & $\mathrm{H}_{7} \mathrm{PMo}_{8} \mathrm{~V}_{4} \mathrm{O}_{40} \cdot 28 \mathrm{H}_{2} \mathrm{O}$ & DBM & 1.5 & 35 & 1 \\
\hline 15 & $\mathrm{H}_{5} \mathrm{PW}_{10} \mathrm{~V}_{2} \mathrm{O}_{40} \cdot 27 \mathrm{H}_{2} \mathrm{O}$ & $\mathrm{DBM}$ & 1.5 & $\mathrm{nd}^{\mathrm{d}}$ & nd $^{\mathrm{d}}$ \\
\hline 16 & $\mathrm{H}_{3} \mathrm{PMo}_{12} \mathrm{O}_{40} \cdot 30 \mathrm{H}_{2} \mathrm{O}$ & DBM & 1.5 & 24 & nd $^{d}$ \\
\hline
\end{tabular}

${ }^{a}$ A mixture of $1 \mathbf{a}(30 \mathrm{mmol})$ and $\mathbf{6 a}(1.5 \mathrm{mmol})$ was reacted in the presence of $\mathrm{Pd}(\mathrm{OAc})_{2}(0.1 \mathrm{mmol}$, $6.7 \mathrm{~mol} \%), \mathrm{HPMoV}$ (0.02 mmol, $1.3 \mathrm{~mol} \%), \mathrm{Na}_{2} \mathrm{CO}_{3}(0.05 \mathrm{mmol}, 3 \mathrm{~mol} \%$ ) and ligand (0.1 mmol, $6.7 \mathrm{~mol} \%)$ under $\mathrm{O}_{2}(1 \mathrm{~atm})$ in EtCOOH $(5 \mathrm{~mL}) .{ }^{\mathrm{b}}$ GC yield based on 6 a used. ${ }^{\mathrm{c}}$ 1a $(20 \mathrm{mmol})$ was used. ${ }^{\mathrm{d}}$ Not detected by GC. ${ }^{\mathrm{e}}$ The reaction was performed in the absence of $\mathrm{Na}_{2} \mathrm{CO}_{3} \cdot{ }^{\mathrm{f}} \mathrm{NaOAC}$ (0.08 mmol) was used instead of $\mathrm{Na}_{2} \mathrm{CO}_{3}$.

Several substituted benzenes were reacted with 2 under varying conditions and the results are summarized in Table 4. 
Table 4. Oxidative coupling of arenes 1 with acrolein (6a) catalyzed by $\mathrm{Pd}(\mathrm{II}) / \mathrm{HPMoV}$. $^{\mathrm{a}}$

Entry

${ }^{a}$ A mixture of 1 (30 mmol) and $\mathbf{6 a}(1.5 \mathrm{mmol})$ was reacted in the presence of $\mathrm{Pd}(\mathrm{OAc})_{2}(0.1 \mathrm{mmol}$, $6.7 \mathrm{~mol} \%), \mathrm{H}_{4} \mathrm{PMo}_{11} \mathrm{VO}_{40} \cdot 26 \mathrm{H}_{2} \mathrm{O}(0.02 \mathrm{mmol}, 1.3 \mathrm{~mol} \%), \mathrm{Na}_{2} \mathrm{CO}_{3}(0.05 \mathrm{mmol}, 3 \mathrm{~mol} \%)$ and DBM $(0.1 \mathrm{mmol}, 6.7 \mathrm{~mol} \%)$ under $\mathrm{O}_{2}(1 \mathrm{~atm})$ in EtCOOH $(5 \mathrm{~mL})$ at $90{ }^{\circ} \mathrm{C}, 1.5 \mathrm{~h} .{ }^{\mathrm{b}}$ Ratio of o-:m:p-isomer. ${ }^{\mathrm{c}} \mathbf{1}(10 \mathrm{mmol})$ was reacted with $\mathbf{6 a}(1.5 \mathrm{mmol})$ by $\mathrm{Pd}(\mathrm{OAc})_{2}(0.1 \mathrm{mmol}, 6.7 \mathrm{~mol} \%)$, $\mathrm{H}_{4} \mathrm{PMo}_{11} \mathrm{VO}_{40} \cdot 26 \mathrm{H}_{2} \mathrm{O}$ (0.02 mmol, $\left.1.3 \mathrm{~mol} \%\right), \mathrm{Na}_{2} \mathrm{CO}_{3}(0.05 \mathrm{mmol}, 3 \mathrm{~mol} \%)$ and acacH (0.1 mmol, $6.7 \mathrm{~mol} \%)$ under $\mathrm{O}_{2}(1 \mathrm{~atm})$ in EtCOOH $(5 \mathrm{~mL})$ at $90{ }^{\circ} \mathrm{C}, 1 \mathrm{~h} .{ }^{d}$ 2,3Dimethoxycinnamaldehyde was obtained $2 \%$ yield as by-product. ${ }^{e}$ Ratio of 2,3-methylenedioxy cinnamaldehyde (7f) to 3,4-methylenedioxy cinnamaldehyde (7f').

The reaction of toluene (1b) with $\mathbf{6 a}$ afforded a mixture of structural isomers $\mathbf{7 b}(o: m: p=13: 44: 43)$ in 59\% yield along with small amounts of dicoupling products (entry 1 ). In the reaction with $t$ butylbenzene (1h) having bulky alkyl group, $m$ - and $p$-products were obtained and $o$-product was not detected at all (entry 2). Anisole (1c) was subjected to react with $\mathbf{6 a}$ to give a mixture of the corresponding coupling products $\mathbf{7 d}(o: m: p=17: 10: 73)$ in $45 \%$ total yield (entry 3$)$. The reaction of 1,2-dimethoxybenzene (1f) with $\mathbf{6 a}$ proceeded in high regioselectivity to produce 3,4dimethoxycinnamaldehyde (7e) (45\%), and the yield of the isomer, 2,3-dimethoxycinnamaldehyde, was found to be less than $2 \%$ (entry 4). In contrast, the reaction of 1,2-methylenedioxybenzene (1i) with 6a led to a 45:55 mixture of 2,3- and 3,4-methylenedioxycinnnamaldehydes (7f and 7f') in 45\% yield (entry 5). 
The oxidative coupling of methacrolein (6b) with 1a was carried out under the conditions as entry 1 , Table 3 (Equation 3).
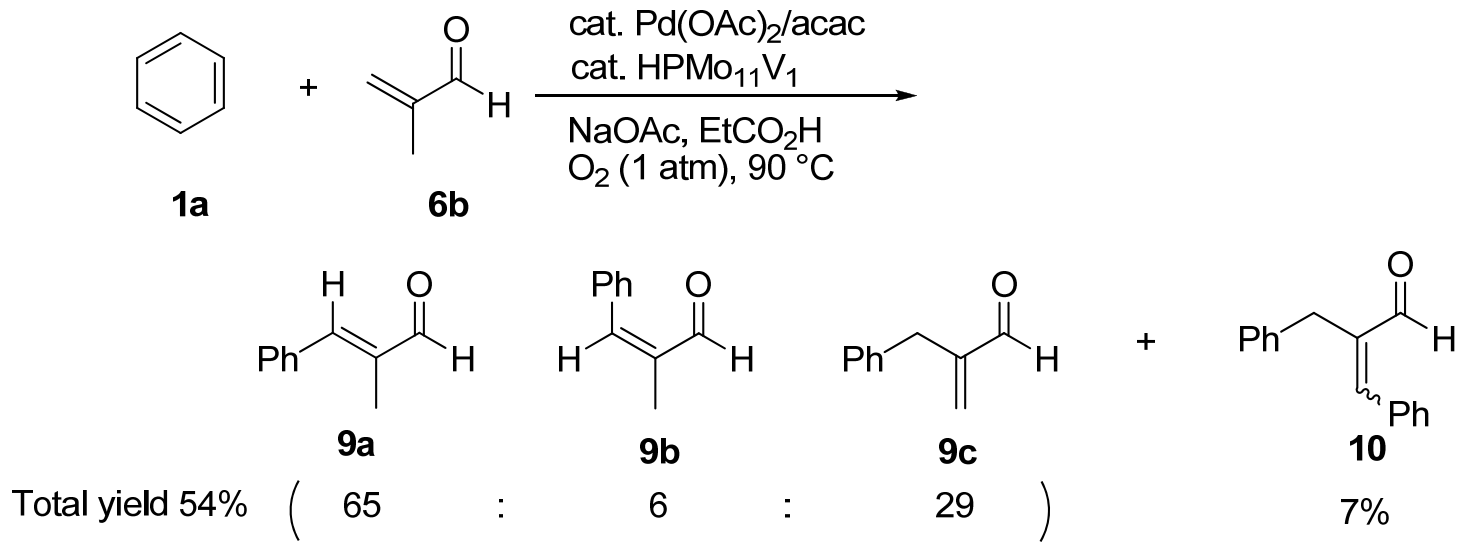

In this reaction, a mixture of three isomeric coupling products consisting of $\mathbf{9 a}, \mathbf{9 b}$ and $\mathbf{9 c}$ were obtained in 54\% yield (9a:9b:9c $=65: 6: 29)$ along with the dicoupling product $\mathbf{1 0}(7 \%)$. Based on the reaction mechanism as illustrated in Scheme 1, the reaction would proceed through a phenyl-palladium intermediate (B') formed by the insertion of phenyl-palladium $\sigma$-complex (A') to $\mathbf{6 b}$. Therefore, 9a, 9b and $9 \mathbf{c}$ can be formed by the following $\beta$-Hydrogen elimination step via path $\mathbf{a}$ (9a and $\mathbf{9 b}$ : elimination of Ha or Ha') and path $\mathbf{b}$ (9c: elimination of $\mathrm{Hb}$ ) (Scheme 2) [12].

Scheme 2. Formation of 9a, 9b, and 9c from phenyl-palladium intermediate (B').

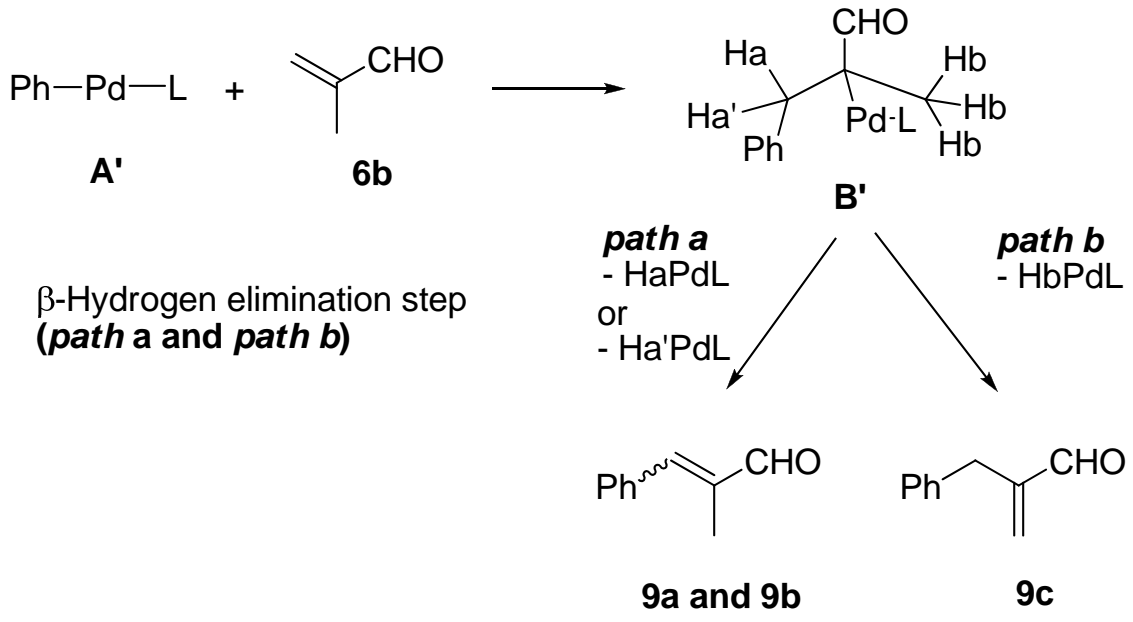

\subsection{Oxidative Mizoroki-Heck type coupling of benzenes with ethylene}

Synthesis of styrene by the oxidative arylation of ethylene with benzene under mild reaction conditions is also an attractive in organic synthesis, because the styrene is produced by the FriedelCrafts reaction of benzene with ethylene followed by dehydrogenation of the resulting ethylbenzene. We performed the aerobic oxidative coupling reaction of benzene (1a) with ethylene (11) catalysed by the $\mathrm{Pd}(\mathrm{OAc})_{2} / \mathrm{H}_{4} \mathrm{PMo}_{11} \mathrm{VO}_{40} \cdot 15 \mathrm{H}_{2} \mathrm{O}$ system, and styrene (12) was obtained as a major adduct. The results under various reaction conditions are summarized in Table 5. 

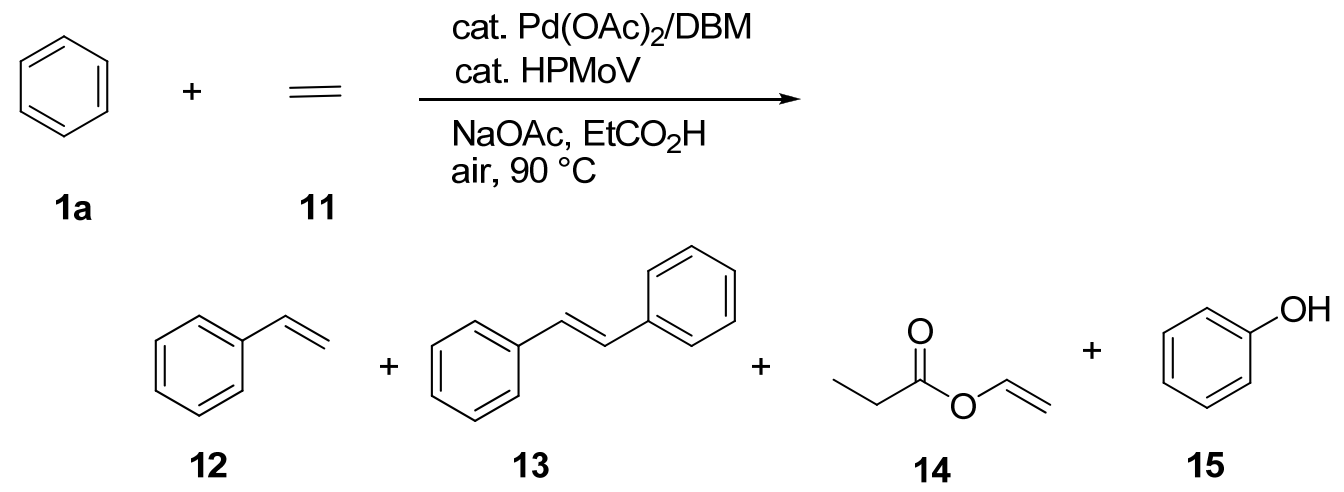

Table 5. Oxidative coupling of benzene (1a) with ethylene (11) catalyzed by Pd(II)/HPMoV. ${ }^{a}$

\begin{tabular}{|c|c|c|c|c|c|c|}
\hline \multirow{2}{*}{ entry } & \multirow{2}{*}{ HPMoV } & \multirow{2}{*}{ Base } & \multicolumn{4}{|c|}{ TON $^{\mathbf{b}}(\mu \mathrm{mol})$} \\
\hline & & & 12 & 13 & 14 & 15 \\
\hline 1 & $\mathrm{H}_{4} \mathrm{PMo}_{11} \mathrm{VO}_{40} \cdot 15 \mathrm{H}_{2} \mathrm{O}$ & $\mathrm{NaOAc}$ & $20(202)$ & $5.2(25)$ & $5.0(50)$ & $3.0(30)$ \\
\hline $2^{c}$ & $\mathrm{H}_{4} \mathrm{PMo}_{11} \mathrm{VO}_{40} \cdot 15 \mathrm{H}_{2} \mathrm{O}$ & $\mathrm{NaOAc}$ & $4.6(46)$ & $\mathrm{nd}^{\mathrm{d}}$ & $8.3(82)$ & $4.5(45)$ \\
\hline $3^{\mathrm{e}}$ & $\mathrm{H}_{4} \mathrm{PMo}_{11} \mathrm{VO}_{40} \cdot 15 \mathrm{H}_{2} \mathrm{O}$ & $\mathrm{NaOAc}$ & $7.5(75)$ & $0.9(4)$ & $6.0(59)$ & 3.9 (39) \\
\hline $4^{\mathrm{f}}$ & $\mathrm{H}_{4} \mathrm{PMo}_{11} \mathrm{VO}_{40} \cdot 15 \mathrm{H}_{2} \mathrm{O}$ & $\mathrm{NaOAc}$ & $14(138)$ & $4.8(24)$ & $3.8(38)$ & $4.9(49)$ \\
\hline 5 & $\mathrm{H}_{4} \mathrm{PMo}_{11} \mathrm{VO}_{40} \cdot 15 \mathrm{H}_{2} \mathrm{O}$ & None & $1.6(16)$ & $n \mathrm{~d}^{\mathrm{d}}$ & $2.0(20)$ & nd $^{\mathrm{d}}$ \\
\hline 6 & $\mathrm{H}_{4} \mathrm{PMo}_{11} \mathrm{VO}_{40} \cdot 15 \mathrm{H}_{2} \mathrm{O}$ & LiOAc & $9.1(90)$ & $2.6(13)$ & $2.9(29)$ & $2.9(29)$ \\
\hline 7 & $\mathrm{H}_{4} \mathrm{PMo}_{11} \mathrm{VO}_{40} \cdot 15 \mathrm{H}_{2} \mathrm{O}$ & KOAc & $5.9(59)$ & $0.8(4)$ & 1.7 (17) & $1.4(14)$ \\
\hline $8^{g}$ & $\mathrm{H}_{4} \mathrm{PMo}_{11} \mathrm{VO}_{40} \cdot 15 \mathrm{H}_{2} \mathrm{O}$ & $\mathrm{Na}_{2} \mathrm{CO}_{3}$ & 19 (188) & $9.7(48)$ & $5.2(52)$ & $7.1(71)$ \\
\hline $9^{\mathrm{h}}$ & $\mathrm{H}_{4} \mathrm{PMo}_{11} \mathrm{VO}_{40} \cdot 15 \mathrm{H}_{2} \mathrm{O}$ & $\mathrm{NaOAC}$ & $14(142)$ & $4.0(20)$ & $3.4(33)$ & $-i$ \\
\hline $10^{\mathrm{j}}$ & $\mathrm{H}_{4} \mathrm{PMo}_{11} \mathrm{VO}_{40} \cdot 15 \mathrm{H}_{2} \mathrm{O}$ & $\mathrm{NaOAc}$ & 12 (119) & $n d^{d}$ & $19(190)$ & $-{ }_{-i}$ \\
\hline $11^{\mathrm{k}}$ & $\mathrm{H}_{4} \mathrm{PMo}_{11} \mathrm{VO}_{40} \cdot 15 \mathrm{H}_{2} \mathrm{O}$ & $\mathrm{NaOAc}$ & $5.3(53)$ & $\mathrm{nd}^{\mathrm{d}}$ & 24 (243) & $-{ }^{\mathrm{i}}$ \\
\hline $12^{1}$ & $\mathrm{H}_{4} \mathrm{PMo}_{11} \mathrm{VO}_{40} \cdot 15 \mathrm{H}_{2} \mathrm{O}$ & $\mathrm{NaOAc}$ & 14 (137) & $4.9(24)$ & $5.2(52)$ & $-{ }^{i}$ \\
\hline 13 & $\mathrm{H}_{5} \mathrm{PMo}_{10} \mathrm{~V}_{2} \mathrm{O}_{40} \cdot 28 \mathrm{H}_{2} \mathrm{O}$ & $\mathrm{NaOAc}$ & $16(154)$ & $4.2(21)$ & $4.4(44)$ & $3.8(38)$ \\
\hline 14 & $\mathrm{H}_{6} \mathrm{PMo}_{9} \mathrm{~V}_{3} \mathrm{O}_{40} \cdot 30 \mathrm{H}_{2} \mathrm{O}$ & $\mathrm{NaOAc}$ & $17(166)$ & $7.7(38)$ & $2.9(29)$ & $4.0(40)$ \\
\hline 15 & $\mathrm{H}_{7} \mathrm{PMo}_{8} \mathrm{~V}_{4} \mathrm{O}_{40} \cdot 28 \mathrm{H}_{2} \mathrm{O}$ & $\mathrm{NaOAc}$ & 19 (192) & $4.9(2.4)$ & $6.4(64)$ & $3.6(36)$ \\
\hline 16 & $\mathrm{H}_{3} \mathrm{PMo}_{12} \mathrm{O}_{40} \cdot 30 \mathrm{H}_{2} \mathrm{O}$ & $\mathrm{NaOAc}$ & $22(223)$ & $11(53)$ & $2.9(29)$ & $0.3(3)$ \\
\hline $17^{\mathrm{m}}$ & $\mathrm{H}_{3} \mathrm{PMo}_{12} \mathrm{O}_{40} \cdot 30 \mathrm{H}_{2} \mathrm{O}$ & $\mathrm{NaOAc}$ & $42(420)$ & $4.4(22)$ & $3.5(35)$ & $\mathrm{nd}^{\mathrm{d}}$ \\
\hline $18^{\mathrm{m}, \mathrm{n}}$ & $\mathrm{H}_{3} \mathrm{PMo}_{12} \mathrm{O}_{40} \cdot 30 \mathrm{H}_{2} \mathrm{O}$ & $\mathrm{NaOAc}$ & 100 (1003) & 67 (335) & 3.9 (39) & $\mathrm{nd}^{\mathrm{d}}$ \\
\hline 19 & $\mathrm{H}_{3} \mathrm{PMo}_{11} \mathrm{WO}_{40} \cdot 27 \mathrm{H}_{2} \mathrm{O}$ & $\mathrm{NaOAc}$ & 24 (239) & $12860)$ & $3.0(30)$ & $\mathrm{nd}^{\mathrm{d}}$ \\
\hline 20 & $\mathrm{H}_{3} \mathrm{PMo}_{10} \mathrm{~W}_{2} \mathrm{O}_{40} \cdot 29 \mathrm{H}_{2} \mathrm{O}$ & $\mathrm{NaOAc}$ & $23(228)$ & 7.8 (39) & $2.8(28)$ & $\mathrm{nd}^{\mathrm{d}}$ \\
\hline 21 & $\mathrm{H}_{4} \mathrm{SiMo}_{12} \mathrm{O}_{40} \cdot 27 \mathrm{H}_{2} \mathrm{O}$ & $\mathrm{NaOAc}$ & $22(218)$ & $7.8(39)$ & $2.9(29)$ & $\mathrm{nd}^{\mathrm{d}}$ \\
\hline 22 & $\mathrm{H}_{5} \mathrm{PW}_{10} \mathrm{~V}_{2} \mathrm{O}_{40} \cdot 27 \mathrm{H}_{2} \mathrm{O}$ & $\mathrm{NaOAc}$ & $1.5(15)$ & trace & $\mathrm{nd}^{\mathrm{d}}$ & nd $^{\mathrm{d}}$ \\
\hline
\end{tabular}

${ }^{\mathrm{a}}$ A mixture of benzene (1a), $\mathrm{Pd}(\mathrm{OAc})_{2}(10 \mu \mathrm{mol}), \mathrm{H}_{4} \mathrm{PMo}_{11} \mathrm{VO}_{40} \cdot 15 \mathrm{H}_{2} \mathrm{O}(10.3 \mathrm{mg}$, ca. $5 \mu \mathrm{mol})$, $\mathrm{NaOAc}(25 \mu \mathrm{mol})$, dibenzoylmethane (DBM) $(30 \mu \mathrm{mol})$ was allowed to react under $0.9 \mathrm{~atm}$ of etyhylene (11) and $1.6 \mathrm{~atm}$ of air in EtCOOH $(2 \mathrm{~mL})$ at $90{ }^{\circ} \mathrm{C}$ for $8 \mathrm{~h} .{ }^{\mathrm{b}}$ Turnover number (TON) based on $\mathrm{Pd}(\mathrm{OAc})_{2}$ used. ${ }^{\mathrm{c}}$ The reaction was performed in the absence of $\mathrm{dbm}$. ${ }^{\mathrm{d}}$ Not detected by GC. ${ }^{\mathrm{e}}$ Dbm $(10 \mu \mathrm{mol})$ was used. ${ }^{\mathrm{f}}$ Acetylacetone was used instead of dbm. ${ }^{\mathrm{g}} \mathrm{Na}_{2} \mathrm{CO}_{3}$ (13 $\left.\mu \mathrm{mol}\right)$ was used. ${ }^{\mathrm{h}}$ The reaction was performed under ethylene/air $=0.5 \mathrm{~atm} / 1 \mathrm{~atm} .{ }^{\mathrm{i}}$ Not determined. ${ }^{\mathrm{j}}$ The reaction was performed under ethylene/air $=3.6 \mathrm{~atm} / 6.4 \mathrm{~atm} .{ }^{\mathrm{k}}$ The reaction was performed under ethylene/air $=5.4 \mathrm{tm} / 9.6 \mathrm{~atm} .{ }^{1}$ The reaction was performed under ethylene/air $=0.9$ atm/29.1 atm. ${ }^{m}$ 1a $(120 \mu \mathrm{mol})$ was reacted with 0.9 atm of 11 in the presence of $\mathrm{Pd}(\mathrm{OAc})_{2}$ $(10 \mu \mathrm{mol}), \mathrm{HPMo}_{11} \mathrm{~V}_{1}(6.8 \mu \mathrm{mol}), \mathrm{NaOAc}(32 \mu \mathrm{mol})$, and dbm $(120 \mu \mathrm{mol})$ in EtCOOH $(8 \mathrm{~mL})$ under $1.6 \mathrm{~atm}$ of air using a $120 \mathrm{~mL}$ autoclave. ${ }^{\mathrm{n}}$ The reaction was performed at $120{ }^{\circ} \mathrm{C}$. 
The reaction of benzene (1a) (30 mmol) was performed with a mixed gas of ethylene (11) (0.9 atm, ca. $2.0 \mathrm{mmol})$ and air $(1.6 \mathrm{~atm})$ in the presence of $\mathrm{Pd}(\mathrm{OAc})_{2}(10 \mu \mathrm{mol}, c a .0 .5 \mathrm{~mol} \%$ based on 11), $\mathrm{H}_{4} \mathrm{PMo}_{11} \mathrm{VO}_{40} \cdot 15 \mathrm{H}_{2} \mathrm{O}(10.3 \mathrm{mg}, \mathrm{ca} .5 \mu \mathrm{mol})$, NaOAc $(25 \mu \mathrm{mol})$, dibenzoylmethane (DBM) (30 $\left.\mu \mathrm{mol}\right)$ and propionic acid $(2 \mathrm{~mL})$ at $90{ }^{\circ} \mathrm{C}$ for $8 \mathrm{~h}$. As a result, styrene (12) was obtained in $202 \mu \mathrm{mol}$ corresponding to 20 turnover numbers of Pd (TON = 20) with concomitant formation of trans-stilbene (13) in $25 \mu \mathrm{mol}$ (TON = 5.2), and vinyl propionate (14) in $50 \mu \mathrm{mol}$ (TON = 5.0), and phenol (15) in $30 \mu \mathrm{mol}(\mathrm{TON}=3.0$ ) (entry 1$)$. Similar to the result reported in the reaction of benzene with acrylates and acrolein, the addition of ligand such as DBM brought about the improvement of the catalytic activity. The amount of DBM was reduced from $30 \mu \mathrm{mol}$ to $10 \mu \mathrm{mol}$, the yield of 12 was decreased to $75 \mu \mathrm{mol}$ (TON = 7.5) (entry 3). The reaction in the absence of DBM gave 12 in low yield and the catalyst was deactivated by forming the Pd black during the reaction course. As a ligand, acetylacetone (acacH) showed the similar catalytic activity for the formation of 12 (entry 4). The addition of the base is necessary to achieve the reaction and the reaction was sluggish in the absence of NaOAc (entry 5). The use of other base such as LiOAc or KOAc instead of NaOAc resulted in the lower TON of Pd for the formation of 12 (entries 6 and 7). Alternatively, $\mathrm{Na}_{2} \mathrm{CO}_{3}$ can also be used as an efficient base in the present reaction (entry 8).

The reaction was markedly influenced by the concentrations of ethylene and air, and the coupling reaction of 1a with 11 was conducted under several varying ethylene/air pressures (entriy 1 vs. entries 9-12). Under the reaction of ethylene/air $=0.9 \mathrm{~atm} / 1.6 \mathrm{~atm}$, TON of Pd for 12 attained maximum $(\mathrm{TON}=20)$ (entry 1$)$. Thus, when the reaction of was performed under lower pressure of ethylene (ethylene/air $=0.5 \mathrm{~atm} / 1 \mathrm{~atm}$ ), the yield of 12 was decreased to $142 \mu \mathrm{mol}(\mathrm{TON}=14)$ (entry 9). Furthermore, the amount of vinyl propionate 14 was increased with increasing of ethylene pressure. The yields of 14 was $190 \mu \mathrm{mol}(\mathrm{TON}=19)$ and $243 \mu \mathrm{mol}(\mathrm{TON}=24)$ when the reaction was carried out under ethylene/air = $3.6 \mathrm{~atm} / 6.6 \mathrm{~atm}$ and 5.4/9.6 atm, respectively (entries 10-11). The reaction under high pressure of air (29.1 atm) with 0.9 atm of ethylene resulted in slightly lower catalytic activity (TON $=14)$ (entry 12).

As mentioned in the previous section, the role of HPMoV is important as the reoxidation system of the reduced $\mathrm{Pd}(0)$ catalyst Therefore, the reaction was performed by the use of HPAs under these conditions. In this reaction, HPAs having various $\mathrm{V}$ contents such as $\mathrm{H}_{5} \mathrm{PMo}_{10} \mathrm{~V}_{2} \mathrm{O}_{40} \cdot 28 \mathrm{H}_{2} \mathrm{O}$, $\mathrm{H}_{6} \mathrm{PMo}_{9} \mathrm{~V}_{3} \mathrm{O}_{40} \cdot 30 \mathrm{H}_{2} \mathrm{O}$ and $\mathrm{H}_{7} \mathrm{PMo}_{8} \mathrm{~V}_{4} \mathrm{O}_{40} \cdot 28 \mathrm{H}_{2} \mathrm{O}$ can be used as reoxidation catalysts and afforded 12 in comparable yields with that of $\mathrm{H}_{4} \mathrm{PMo}_{11} \mathrm{VO}_{40} \cdot 15 \mathrm{H}_{2} \mathrm{O}$ (entries 13 to 15). It was found that $\mathrm{H}_{3} \mathrm{PMo}_{12} \mathrm{O}_{40} \cdot 30 \mathrm{H}_{2} \mathrm{O}$ not including $\mathrm{V}$ ion was found to serve a good reoxidation catalyst (entries 16-18) and the highest total TON of Pd for the formation of 12 and 13 was reached to 167, under the optimum reaction conditions (entry 18). In addition, various heteropoly acids such as $\mathrm{H}_{4} \mathrm{PMo}_{11} \mathrm{WO}_{40} \cdot 27 \mathrm{H}_{2} \mathrm{O}$, $\mathrm{H}_{3} \mathrm{PMo}_{10} \mathrm{~W}_{2} \mathrm{O}_{40} \cdot 29 \mathrm{H}_{2} \mathrm{O}$, and $\mathrm{H}_{4} \mathrm{SiMo}_{12} \mathrm{O}_{40} \cdot 27 \mathrm{H}_{2} \mathrm{O}$ showed similar catalytic activities (entries 19-21). However, the heteropoly acid without molybdenum ion such as $\mathrm{H}_{5} \mathrm{PW}_{10} \mathrm{~V}_{2} \mathrm{O}_{40} \cdot 27 \mathrm{H}_{2} \mathrm{O}$ was found to be inactive for the present reaction (entry 22). It is noteworthy that phenol (15) was not produced in the reaction using heteropoly acids not including $\mathrm{V}$ ion. By judging of these results, it is considered that molybdenum ion in the heteropoly acids is an essential component to promote the reoxidation of the reduced $\mathrm{Pd}(0)$ to $\mathrm{Pd}(\mathrm{II})$ for the present reaction. 


\section{Experimental}

\subsection{General procedure for oxidative coupling of benzene (1a) with ethyl acrylate (2a) (entry 1, Table 1)}

A solution of $\mathrm{Pd}(\mathrm{OAc})_{2}(0.1 \mathrm{mmol}), \mathrm{H}_{4} \mathrm{PMo}_{11} \mathrm{~V}_{1} \mathrm{O}_{40} \cdot 30 \mathrm{H}_{2} \mathrm{O}\left(\mathrm{HPMo}_{11} \mathrm{~V}_{1}\right)$ (46.7 mg, ca. $\left.0.02 \mathrm{mmol}\right)$, $\mathrm{NaOAc}(0.08 \mathrm{mmol})$, acetylacetone $(0.1 \mathrm{mmol})$, benzene $(\mathbf{1 a})(30 \mathrm{mmol})$ and ethyl acrylate (2a) $(1.5 \mathrm{mmol})$ in propionic acid $(5 \mathrm{~mL})$ was placed in a round bottom flask $(30 \mathrm{~mL})$ equipped with a balloon filled with $\mathrm{O}_{2}$, and the mixture was allowed to react under stirring at $90{ }^{\circ} \mathrm{C}$ for $2.5 \mathrm{~h}$. The reaction gave ethyl cinnamate (3a), $\beta$-phenylcinnamate (4a) and 3-propionylacrylate (5) in 74\%, 14\% and $5 \%$ yields, respectively. All yields were determined by GLC analysis using nonane as internal standard. The products were characterized by ${ }^{1} \mathrm{H}$ - and ${ }^{13} \mathrm{C}-\mathrm{NMR}$ and GC-MS, respectively.

\subsection{General procedure for oxidative coupling of benzene (1) with ethylene (11) (entry 1 in Table 5)}

Caution: In order to avoid an explosion of a mixture of ethylene and air, the reaction was carried out at the ethylene concentration deviated from explosion limits ranging in 3.1 to $32 \%$. To a $50 \mathrm{~mL}$ stainless steel autoclave equipped with a magnetic stir bar were placed $\operatorname{Pd}(\mathrm{OAc})_{2}(10 \mu \mathrm{mol})$, $\mathrm{H}_{4} \mathrm{PMo}_{11} \mathrm{VO}_{40} \cdot 15 \mathrm{H}_{2} \mathrm{O}$ (10.4 mg, ca. $5 \mu \mathrm{mol}$ ), NaOAc (25 $\left.\mu \mathrm{mol}\right)$, dibenzoylmethane (DBM) (30 $\left.\mu \mathrm{mol}\right)$, and benzene (1a) $(30 \mathrm{mmol})$ and propionic acid $(2 \mathrm{~mL})$. To the autoclave was introduced with $0.9 \mathrm{~atm}$ of ethylene gas (11) and $1.6 \mathrm{~atm}$ of air, and the mixture was stirred at $90{ }^{\circ} \mathrm{C}$ for $8 \mathrm{~h}$. All yields were detected by GLC analysis using dodecane as internal standard. The products were identified through a comparison of these analytical data with those of authentic samples.

\section{Conclusions}

In conclusion, we have shown the first direct oxidative coupling of benzenes with acrylates, $\alpha, \beta$ unsaturated aldehydes, and ethylene under atmospheric dioxygen and air by using $\mathrm{Pd}(\mathrm{OAc})_{2}$ combined with HPMoV. In this catalytic system, addition of ligand such as acetylacetone (acacH) and dibenzoylmethane (DBM) was effective to suppress the $\mathrm{Pd}(0)$ black precipitation. All the presented oxidative coupling reactions in this review uses molecular oxygen as terminal oxidant. Therefore, these reactions provide very useful organic transformations from environmental and economical points of view.

\section{Acknowledgements}

We acknowledge that these studies were carried out in collaboration with co-workers at Kansai University listed in the references. This work was supported by a Grant-in-Aid for Scientific Research on Priority Areas “Advanced Molecular Transformation of Carbon Resources”, KAKENHI (No. 13853008 and 15036265) from the Ministry of Education, Culture, Sports, Science and Technology, Japan, and "High-Tech Research Center" Project for Private Universities: matching fund subsidy from the Ministry of Education, Culture, Sports, Science and Technology, 2005-2009. We also thank Nippon Inorganic Colour \& Chemical Co. Ltd. for a gift of heteropoly acids. 


\section{References and Notes}

1. Mizoroki, T.; Mori, K.; Ozaki, A. Arylation of olefin with aryl iodide catalyzed by palladium. Bull. Chem. Soc. Jpn. 1971, 44, 581.

2. Heck, R.F.; Nolley, J.P., Jr. Palladium-catalyzed vinylic hydrogen substitution reactions with aryl, benzyl, and styryl halides. J. Org. Chem. 1972, 37, 2320-2322.

3. Gooßen, L.; Gooßen, K. Waste-minimized Mizoroki-Heck Reactions. In The Mizoroki-Heck Reaction; Oestreich, M., Ed.; Wiley: Chichester, UK, 2009; pp. 163-178.

4. Trepohl, V.T.; Oestreich, M. Palladium-catalyzed Arylation Reactions Of Alkenes (MizorokiHeck Reaction And Related Processes). In Modern Arylation Methods; Ackermann, L., Ed.; Wiley-VCH: Weinheim, Germany, 2009; pp. 221-269.

5. Leeuwen, P. W.N.M.; de Vries, J.G. Palladium-catalyzed Oxidative Vinylation. In Handbook of C-H Transformation; Dyker, G., Ed.; Wiley-VCH: Weinheim, Germany, 2005; Volume 1, pp. 203-212.

6. Fujiwara, Y.; Kitamura, T. Fujiwara reaction: Palladium-catalyzed hydroarylations of alkynes. In Handbook of C-H Transformation; Dyker, G., Ed.; Wiley-VCH: Weinheim, Germany, 2005; Volume 1, pp. 194-202.

7. Jia, C.; Kitamura, T.; Fujiwara, Y. Catalytic functionalization of arenes and alkanes via C-H bond activation. Acc. Chem. Res. 2001, 34, 633-639.

8. Moritani, I.; Fujiwara, Y. Aromatic substitution of styrene-palladium chloride complex. Tetrahedron Lett. 1967, 1119-1122.

9. Fujiwara, Y.; Moritani, I.; Danno, S.; Asano, R.; Teranishi, S. Aromatic substitution of olefins. VI. Arylation of olefins with palladium(II) acetate. J. Am. Chem. Soc. 1969, 91, 7166-7169.

10. Shue, R.S. Catalytic coupling of aromatics and olefins by homogeneous palladium (II) compounds under oxygen. Chem. Commun. 1510-1511.

11. Maruyama, O.; Yoshidomi, M. Fujiwara, Y.; Taniguchi, H. Pd(II)-Cu(II)-catalyzed synthesis of mono- and dialkenyl-substituted five menbdered aromatic heterocycles. Chem. Lett. 1229-1230.

12. Tsuji, J.; Nagashima, H. Palladium-catalyzed oxidative coupling of aromatic compounds with olefins using tert-butyl perbenzoate as a hydrogen acceptor. Tetrahedron 1984, 40, 2699-2702.

13. Jia, C.; Lu, W.; Kitamura, T.; Fujiwara, Y. Highly efficient Pd-catalyzed coupling of arenes with olefins in the presence of tert-butyl hydroperoxide as oxidant. Org. Lett. 1999, 1, 2097-2100.

14. Dams, M.; de Vos, D.E.; Celen, S.; Jacobs, P.A. Toward waste-free production of Heck products with a catalytic palladium system under oxygen. Angew. Chem. Int. Ed. 2003, 42, 3512-3515.

15. Boele, M.D.K.; van Strijdonck, G.P.F.; de Vries, A.H.M. Kamer, P.C.J.; de Vries, J.G.; van Leeuwen, P.W.N.M. Selective Pd-catalyzed oxidative coupling of anilides with olefins through C$\mathrm{H}$ bond activation at room temperature. J. Am. Chem. Soc. 2002, 124, 1586-1587.

16. Beck, E.M.; Grimster, N.P.; Hatley, R.; Gaunt, M.J. Mild aerobic oxidative palladium(II) catalyzed $\mathrm{C}-\mathrm{H}$ bond functionalization: regioselective and switchable $\mathrm{C}-\mathrm{H}$ alkenylation and annulations of pyrroles. J. Am. Chem. Soc. 2006, 128, 2528-2529.

17. Grimster, N.P.; Gauntlett, C.; Godfrey, C.R.A.; Gaunt, M.J. Palladium-catalyzed intermolecular alkenylation of indoles by solvent-controlled regioselective $\mathrm{C}-\mathrm{H}$ functionalization. Angew. Chem. Int. Ed. 2005, 44, 3125-3129. 
18. Yokota, T.; Tani, M.; Sakaguchi, S.; Ishii, Y. Direct coupling of benzene with olefin catalyzed by $\mathrm{Pd}(\mathrm{OAc})_{2}$ combined with heteropolyoxometalate under dioxygen. J. Am. Chem. Soc. 2003, 125, 1476-1477.

19. Tani, M.; Sakaguchi, S.; Ishii, Y. $\operatorname{Pd}(\mathrm{OAc})_{2}$-catalyzed oxidative coupling of benzenes with olefins in the presence of molybdovanadophosphoric acid under atmospheric dioxygen and air. J. Org. Chem. 2004, 69, 1221-1226.

20. 19Yamada, T.; Sakaguchi, S.; Ishii, Y. Oxidative coupling of benzenes with $\alpha, \beta$-unsaturated aldehydes by the $\mathrm{Pd}(\mathrm{OAc})_{2} /$ molybdovanadophosphoric acid $/ \mathrm{O}_{2}$ system, J. Org. Chem. 2005, 70, 5471-5474.

21. Yamada, T.; Sakaguchi, S.; Ishii, Y. Oxidative Coupling Of Benzenes with A,B-Unsaturated Aldehydes By $\mathrm{Pd}(\mathrm{Oac})_{2} / \mathrm{Hpmov} / \mathrm{O}_{2}$ System. In Catalysis for Fine Chemical Synthesis; Roberts, S.M., Whittall, J., Eds.; Wiley: Chichester, UK, 2007; Volume 5, pp. 275-278.

22. Yamada, T.; Sakakura, A.; Sakaguchi, S.; Obora, Y.; Ishii, Y. Oxidative arylation of ethylene with benzene catalyzed by $\mathrm{Pd}(\mathrm{OAc})_{2} /$ heteropoly acid/O ${ }_{2}$ system. New J. Chem. 2008, 32, 738-742.

23. Yokota, T.; Sakaguchi, S.; Ishii, Y. Aerobic oxidation of benzene to biphenyl using a Pd(II)/molybdovanadophosphoric acid catalytic system, Adv. Synth. Catal. 2002, 344, 849-854.

Sample Availability: Samples of the compounds are available from the authors.

(C) 2010 by the authors; licensee Molecular Diversity Preservation International, Basel, Switzerland. This article is an open-access article distributed under the terms and conditions of the Creative Commons Attribution license (http://creativecommons.org/licenses/by/3.0/). 